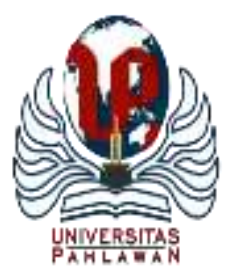

Edukatif : Jurnal Ilmu Pendidikan Volume 4 Nomor 1 Tahun 2022 Halm 1157 - 1169 EDUKATIF: JURNAL ILMU PENDIDIKAN

Research \& Learning in Education

https://edukatif.org/index.php/edukatif/index

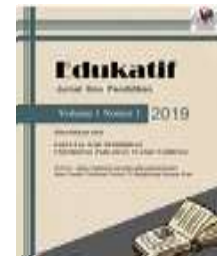

\title{
Pemaknaan Kembali Konsep Wanita di Era Modern (Studi Atas Gagasan Kaum Feminisme dan Fundamentalis)
}

\author{
Rizal Al Hamid \\ Universitas Islam Negeri Sunan Kalijaga Yogyakarta, Indonesia \\ E-mail : rizal.alhamid@ uin-suka.ac.id
}

\begin{abstract}
Abstrak
Diskusi perempuan tidak lagi menjadi hal yang tabu. Entitasnya lebih meningkat pasca munculnya gerakan feminisme, yang menyuarakan hak-hak perempuan akan fakta ketimpangan sosial selama ini. Gerakan ini memang belum lama muncul, namun kehadirannya banyak melahirkan gagasan progresif, yang menjawab kegelisahan sebagian besar kaum hawa di era serba digital ini. Pendapat lain mengatakan bahwa gerakan feminisme merupakan cabang dari isu-isu seputar liberalisme, yang telah menjangkiti kaum muslimin di Indoneisa. Kehadirannya sekaligus menuai kritikan keras oleh kaum fundamentalis, yang berusaha menjaga keotentikan sumber-sumber otoritatif, yaitu Al-Qur'an dan Hadits, sehingga dua kubu tersebut, hampir sukar untuk dipadukan. Tulisan ini merupakan kajian kepustakaan yang menggunakan metode analisis-deskriptif. Hasilnya, bahwa dalam memaknai feminisme, tidak bisa disamakan dengan konsep bertauhid yang memiliki prinsip absolut. Kajian feminisme merupakan bagian dari konsep mu'amalah atau inteaksi sosial dalam berislam, sehingga dalam praktinya, segala bentuk dalil hukum (baik naqli maupun 'aqli) yang dimiliki oleh dua kubu, tidak memilik hak untuk saling menjastifkasi atas kebenaran, karena dalam konsep bersosial, islam memiliki kelenturan hukum yang relevan bagi setiap zaman. Kebenaran (dalam diskursus feminisme) adalah perpihak pada peningkatan ketaqwaan yang dimiliki oleh setiap individu, sehingga benar atau tidaknya istinbath hukum atau gagasan yang ditawarkan oleh dua kubu, semuanya dikembalikan pada masing-masing individu.
\end{abstract}

Kata Kunci: Peran wanita, Era Modern, Kamum Feminis, Kaum Fundamentalis, Gender.

\begin{abstract}
Discussion about women is no longer taboo. Her entity became more and more increased after the emergence of the feminist movement, which voiced women's rights to the fact of social inequality for centuries. This movement has indeed emerged recently, but its presence has produced many progressive ideas, which answer the anxiety of most women in this all-digital era. One opposite side says that this feminist movement is a branch of the issues surrounding liberalism, which have plagued many human beings, especially Muslims in Indonesia. Their presence at the same time has been heavily criticized by fundamentalists, who try to maintain the authenticity of the authoritative sources, namely the Al-Qur'an and hadith, so that the two camps are almost difficult to reconcile. In this simple article, we try to be as objective as possible to dissect these two camps, to find a bright spot, so that in living life in this modern era, we will no longer be preoccupied with unsuspecting disputes.
\end{abstract}

Keywords: Women's Role, Modern Era, Feminist, Conservative, Fundamentalist, Gender.

Copyright (c) 2022 Rizal Al Hamid

$\triangle$ Corresponding author

Email : rizal.alhamid@uin-suka.ac.id

DOI : https://doi.org/10.31004/edukatif.v4i1.2072 ISSN 2656-8071 (Media Online) 


\section{Pemaknaan Kembali Konsep Wanita di Era Modern (Studi Atas Gagasan Kaum Feminisme dan Fundamentalis)-Rizal Al Hamid}

DOI: https://doi.org/10.31004/edukatif.v4i1.2072

\section{PENDAHULUAN}

Lebih dari 12 abad masa keemasan islam, hingga pernah menguasai 2/3 belahan bumi ini (Philip K. Hitti: 2002), ia selalu memilik daya tarik bagi siapa saja ingin mengenal lebih jauh tentangnya. Bukan menjadi rahasia lagi, bahwa metode dan konsep islam dalam berekspansi ke sebuah wilayah, khususnya wilayah di mana belum ada satupun dari penduduknya yang beragama islam, para muslimin selalu menebarkan kemakmuran, dan perdamaian, tanpa adanya pertumpahan darah walau setetespun.

Hal yang menarik dalam sebuah wacana dan kajian ilmiah tentang fakta di atas adalah, hampir tidak ada satupun peran signifikan seorang wanita, dalam kaitannya dengan kejayaan islam di berbagai belahan dunia, hingga para wanitanya terlibat dalam sebuah sruktur formatif organisasi, publik figur, hingga menjadi seorang pemimpin. Belum lagi sumber-sumber otoritatif, seperti Al-Qur'an dan Hadits, serta ijtihad para ulama, yang banyak menyinggung tentang kedudukan wanita, bahwa posisi mereka selalu berada satu strata di bawah kaum laki-laki. Hal ini ternyata menjadi senjata ampuh bagi para fundamentalis dan kaum konservatif, yang berdalih bahwa kejayaan islam akan dapat direbut kembali apabila wanitanya ditempatkan pada tempat yang semestinya. Ya, seperti yang terdapat dalam kitab-kitab tafsir conventional, Imam Zamahsyari misalnya, beliau mengatakan bahwa jika seandainya wanita itu sama dengan laki-laki, tentu Allah sudah memberi tampuk kenabian kepada mereka. Lebih dari itu, beliau mengatakan juga bahwa jabatan fungsional, seperti pemimpin Negara hingga lini terkecil, haruslah para kaum Adam yang berhak mengembannya (Abu al-Qasim al-Zamakhsyari, 2008). Dalam tafshilnya, bahkan beliau memberikan perincian yang cukup detail, bahwa keunggulan laki-laki dari perempuan, sekurang-kurangnya, terdapat enam hal pokok yang mendasarinya, yaitu akal ('aql), ketegasan sikap (al-Hazm), semangat (al-'azm), keperkasaan (al-Quwwah), keberanian (alfarusiyah), dan ketangkasan (al-ramy (Al-Zamakhsyari, 2008).

Bukan hanya satu atau dua mufassir saja yang mengatakan demikian, hal senadapun diutarakan oleh para mufassir lainnya, seperti Imam al-Razi (Al-Din, 2008). Imam al-Baghawi (Al-Baghowi, 2009), bahkan hingga Imam Ibnu katsir, ulama otoritatif yang karya-karyanya kerap menjadi rujukan bagi para generasi setelahnya, bahkan hingga sekarang (Ibnu Katsir, 2013). Kesimpulannya adalah, bahwa keunggulan laki-laki merupakan bentuk kodrati, dan menjadi nilai universal lintas zaman, sehingga kapanpun dan di manapun, kehadiran kaum laki-laki selalu mendefinisikan nilai-nilai superior, dan wanitanya hanya sebatas makhluk inverior (the second class), yang kehadirannya selalu dinomorduakan.

Lain kaum fundamentalis, lain pula kaum feminis, mereka dengan sekuat tenaga berusaha tidak hanya sebatas merekonstruksi sebuah konsep bersosial dan bernegara bagi para wanitanya, namun juga mendekonstruksi ajaran-ajaran dan habitus yang sekian abad telah mengakar begitu kuat di kalangan kaum muslimin. Tidak tanggung-tanggung, pendekatan teolgis dengan melibatkan teks-teks agama, seperti AlQur'an dan Hadits, kerap mereka gunakan, sebagai alat analisis, yang sedemikian rupa telah melalui proses kontekstualisasi, baik dari sudut pandang historis, kausalitas, hingga tujuan dan dampak, agar menjadi produk hukum yang relevan di era modern saat ini.

Dahulu saat kaum muslimin masih memegang tampuk kendali dunia, mungkin tidak pernah terfikir oleh mereka, bahwa kelak suatu saat seorang wanita akan memiliki peran sejajar dengan laki-laki, memiliki fugur di mata publik, menduduki peran strategis, bahkan hingga menjadi pemimpin bagi kaum Adam. Bagaimana tidak, peran wanita yang saat itu selalu menjadi the second class, tiba-tiba muncul di mata publik, sebagai figur superior, yang kehadirannya dirasa mampu merubah dunia agar dapat lebih baik.

Keadaan patriarki di masa itu bukan saja sebatas adat istiadat hingga menjadi budaya universal di hampir seluruh belahan dunia, namun dalam internal umat islam sendiri, Rasulullahpun pernah bersabdah bahwa "tidak akan berjaya suatu kaum jika dipimpin oleh seorang wanita." ( Abu Abdillah Muhammad ibn

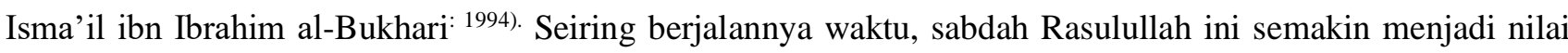
kekuatan bagi hampir seluruh penganut agama islam di seluruh penjuru dunia. 
Pada akhirnya, metode pembacaan teks-teks keagamaan, dan pemaknaan ulang akan hal tersebut dirasa harus dilakukan secara komprehensif, agar supaya tidak terjadi bias pemahaman, lantaran zaman dan kondisi sosial budaya di masing-masing wilayah telah berubah. Bukan berpihak pada salah satu di antara keduanya, namun kita menyadari, bahwa tidak selamanya sisi normatif selalu menjadi bahan pijakan, pun sebaliknya, tidak selamanya sisi historis menjadi dewa bagi penganut islam progresif, teruntuk bagi kaum feminis, yang gigih menyuarakan hak-hak dan keadilan bagi kaum perempuan. Terdapat hal yang lebih substantif secara teologis, epistemologis, hingga metode pemahaman akan sumber-sumber teks otoritatif dan reverentif, yang dapat digali lebih dalam, agar dapat menghasilkan produk hukum yang shalih li kulli zaman wa makan.

Hal-hal semacam ini (baca: diskusi tentang gender) perlu mendapat perhatian khusus, agar dalam konsepnya, al-muhafadzatu 'ala qadim al-shalih, tidak lekang oleh zaman begitu saja, (dalam hal ini adalah gerakan kaum feminis). Atau dalam arti lain, bahwa jangan sampai hadirnya kaum feminis di era modern saat ini, menghilangkan sepenuhnya kodrat wanita, yang telah lama dijaga oleh Al-Qur'an dan Sunnah lantaran dengan dalih kesetaraan, memberantas ketidakadilan, dan anti diskriminasi. Sebaliknyapun demikian, dengan berkembangnya akan kebutuhan manusia, baik melalui ilmu pengetahuan, kebudayaan, nilai-nilai humanis, tatanan sosial-politik, hingga hubungan diplomatis antar Negara, patut bagi kita untuk memilah dan memilih mana yang sekirangan baik untuk maslahat publik, dan mana yang memiliki banyak kemudharatan. Seperti sambungan dalam kaidah fiqh di atas yaitu wa al-akhdu bi al-jadid al-ashlah. Jika sekiranya dalam sebuah tatanan sosial-budaya, politik, pendidikan, dan ruang publik pada umumnya terdapat kebutuhan akan figur seorang perempuan, maka hal tersebut tidak menjadi perkara besar, selama kita sebagai manusia, khususnya kaum perempuan itu sendiri, mampu menjaga norma-norma dalam bersosial, bernegara, hingga beragama.

\section{METODE PENELITIAN}

Penelitian ini berjenis studi pustaka dengan teknik pengumpulan data menggunakan metode dokumentasi dari berbagai sumber literatur dan referensi yang berupa buku-buku, jurnal serta sumber internet yang relefan dengan tema pembahasan yang berkaitan dengan peran wanita dalam hubungannya dengan isuisu feminisme.

\section{HASIL DAN PEMBAHASAN PENELITIAN}

\section{Definisi Feminisme}

Secara etimologis, feminisme merupakan paham tentang wanita, yang sekaligus di dalamnya juga mengandung unsur gerakan. Dikatakan demikian karena tujuan feminisme dimaksudkan agar pengalaman, identitas, cara berpikir, dan bertidaknya seorang perempuan, bisa dilihat sama seperti laki-laki. Lebih lanjut, bahwa feminisme adalah paham atau keyakinan, bahwa perempuan benar-benar bagian dari alam manusia, bukan dari bagian yang lain, yang menuntut kesetaraan dengan laki-laki dalam setiap aspek kehidupan, tanpa melihat kodrat dan fitrahnya. Kesetaraan ini biasanya disebut juga dengan istilah kesetaraan gender (gender equality). Dalam hal ini, kesetaraan gender dapat diartikan sebagai adanya kesamaan kondisi laki-laki dengan perempuan, dalam mendapatkan hak-haknya sebagai makhluk sosial. Hal ini diharapkan agar mampu berperan dan berpatisipasi dalam semua kegiatan, baik politik, ekonomi, sosial, budaya, pendidikan, dsb.

Para filosof feminisme telah mengkatagorikan fundamental filsafat Barat, dan mendefinisikan permasalahan yang mendasar dari epistiologi barat dan teori praktek orang barat, yakni bersumber dari maskulin terhadap pemisahan dan domonasi. Filsafat feminisme sendiri merupakan suatu cara berpikir yang berarti menuntut adanya logika, metodologi, dan sebagainya, yang juga tidak luput dari kelemahan. Feminisme menolak ketidakadilan sebagai akibat masyarakat patriarkhi, menolak sejarah, dan filsafat sebagai disiplin yang berpusat pada laki-laki. 
1160 Pemaknaan Kembali Konsep Wanita di Era Modern (Studi Atas Gagasan Kaum Feminisme dan Fundamentalis)- Rizal Al Hamid

DOI: https://doi.org/10.31004/edukatif.v4i1.2072

\section{Definisi Fundamentalisme}

Terma fundamentalisme berasal dari kata fundamen yang berarti asas, dasar, hakikat. Adapun dalam bahasa Inggris, istilah fundamentalis berarti pokok. Sedangkan dalam bahasa Arab, kata fundamentalisme diistilahkan dengan ushuliyyah. Kata ushululiyyah sendiri berasal dari kata ushul yang artinya pokok. Dengan demikian, fundamentalisme adalah faham yang menganut tentang ajaran dasar dan pokok yang berkenaan dengan ajaran keagamaan atau aliran kepercayaan.

Adapun secara historis, istilah fundamentalisme lahir dalam lingkungan tradisi kristen (Burhanuddin, Nunu, 2018). Digunakan pertama kalinya untuk menamai sebuah gerakan agresif dan konservatif di lingkungan gereja Kristen Protestan di Amerika Serikat pada masa pasca perang dunia I, yang tercetus terutama di lingkungan gereja-gereja Baptis, Desciple dan Presbyterian dan memperoleh dukungan dari kalangan kelompok-kelompok kependetaan (Fauzan, 2019). Gerakan ini kemudian membentuk suatu aliran pemikiran keagamaan yang cenderung menafsirkan teks-teks keagamaan (scipture) secara rigid (kaku) dan literalis (harfiah). Kecenderungan corak penafsiran demikian, menurut para tokoh yang biasa dianggap sebagai fundamentalis adalah perlu, demi menjaga kemurnian doktrin dan pelaksanaanya, di samping juga karena didorong adanya keyakinan, bahwa penerapan doktrin secara utuh, adalah satu-satunya cara dalam menyelamatkan manusia dari kehancuran.

Menurut Emarah yang dikutip oleh Burhanuddin, fundamentalisme adalah produk budaya Barat yang dipaksakan untuk diterapkan pada situasi-situasi khusus masyarakat muslim modern. Awalnya ia adalah gerakan Kristen Protestan Amerika pada abad 19 M yang lebih dikenal dengan sebutan Gerakan Millenium. Gerakan ini mengimani kembalinya Al-Masih secara fisik dan materi ke dunia, 1000 tahun sebelum datangnya hari kiamat (Burhanuddin, Nunu, 2018). Lebih lanjut menurutnya, bahwa kemunculan mereka lebih disebabkan adanya penakwilan yang liberal atas teks Alkitab dan penolakan seutuhnya atas kehidupan sekular yang mewabah di Barat pada masa awal abad 19 M. Oleh karena itu, mereka mengadakan seminar-seminar dan membentuk organisasi-organisasi untuk memprogandakan ajaran-ajarannya. Seperti pada tahun 1902 Organisasi Kitab Suci telah berhasil mempublikasikan 12 buku dengan judul "Fundamentals" sebagai pembelaan atas penafsiran Injil secara liberal, serta menangkal kritik dan penakwilan atas kandungan Injil, dan pada tahun 1919, berdirilah Yayasan Fundamentalisme Kristen Internasional. Oleh karenanya, dalam sejarah Islam tidak dikenal istilah ini, dan tidak tampak bersinggungan dengan gerakan fundamentalisme itu sendiri.

\section{Kehadiran Kaum Feminis dan Fundamentalis}

Husein Muhammad mengatakan, bahwa dalam satu abad terakhir ini (Arivia, Gadir, 2018), diskursus tentang feminisme telah menjadi perbincangan hangat bagi masyarakat dunia, termasuk dunia (Muhammad, 2012). Feminisme, sebuah gerakan yang mengkritik, meyanggah, memperjuangkan wanita, mempertanyakan entitasnya, hingga berusaha mencari solusi dari permasalahan-permasalahan yang terjadi di era modern saat ini. Satu akar permasalahan yang menjadi kerikil di sepatu para kaum feminis, yaitu rasa ketidakadilan. Akar permasalahan ini kini telah menjadi pohon yang begitu lebat, hingga hampir-hampir tidak ada yang mampu untuk mencabutnya. Hampir di seluruh belahan dunia, khususnya Negara dengan jumlah populasi muslim yang relatif banyak, seperti di Asia tenggara, sebagian Negara eropa, hingga Amerika, suara kaum feminis kian hari kian mencuat dan diiyakan oleh banyak pihak, hingga tidak sedikit dari para wanitaanya, keluar dari zona pingitan, yang telah mentradisi turun temurun.

Di sisi lain, terdapat kaum yang selalu menentang akan gerakan tersebut, sebagian menaminya dengan kaum fundamentalis, konservatif, atau ekslusif. Kaum fundamentalis bisa dikatakan penyambung lidah dari para ulama pendahulunya, hingga berpangkal tolak pada teks-teks, seperti Al-Qur'an dan Hadits, serta pendapat-pendapat ulama otoritatif lintas zaman (Dahlan, 2019). Pada umumnya, kaum konservatiffundamentalis selalu menganggap bahwa esensi dari sebuah sabdah Rasulullah, hingga graduasi wahyu yang diterimanya (baca:Al-Qur'an) adalah nilai final dari sebuah ajarah, sehingga sepeninggalan beliau, tidak ada 


\section{Pemaknaan Kembali Konsep Wanita di Era Modern (Studi Atas Gagasan Kaum Feminisme dan Fundamentalis)- Rizal Al Hamid \\ DOI: https://doi.org/10.31004/edukatif.v4i1.2072}

yang berhak untuk menambah, mengurangi, apalagi sampai memodifikasi sedemikian rupa, sehingga menimbulkan kerancauan pada setiap ajarannya. Satu hal yang menajdi keresahan kaum fundamentalis akan sederet pemikiran-pemikiran gerakan feminis yaitu, sifat latah mereka terhadap kontaminasi dunia barat serta Eropa modern, yang belakangan ini telah dan masih menjangkit para pemikir muslim, bahkan hingga pada titik darurat.

Problematikanya, selama ini kita dibuat bingung oleh keadaan di atas, baik itu realita sosial, maupun ideologi dari para fanatisan terhadap konsep dan gaya pemikiran keduanya, yaitu kaum feminis dan fundamentalis. Di satu sisi banyak dari redaksi hadits yang mewanti-wanti para wanita untuk selalu menjaga harga dirinya dengan tidak keluar rumah melainkan harus dengan mahramnya, dan beserta seperangkat haditshadits misoginis lainnya. Pesan-pesan dalam banyak hadits Rasulullah tersebut sangat begitu mengakar hingga mampu diaplikasikan oleh generasi setelahnya, bahkan hingga berabad-abad lamanya. Belum lagi ayat alQur'an seperti dalam QS al-Nisa 4:34, yang menyatakan bahwa laki-laki adalah qawwam bagi wanita. Satu sisi yang lain mengatakan bahwa readksi Al-Qur'an hadits juga harus selalu memiliki relevasi sejalan dengan perubahan zaman, dan zaman modern inilah saatnya wanita memiki karya dimata publik.

Realita ini diperkuat oleh agrumentasi-argumentasi para kaum feminis, yang dengan gigihnya memperjuangkan jati diri para kaum perempuan, agar bagaimana mereka memiki peranan yang setara dengan para kaum Adam. Tidak heran jika saat kita membaca buah karya para kuam feminis, seperti Amina Wadud, Musdah Mulia, Asghar Ali, Husein Muhammad, dll, sebelum kita membaca karya-karya mereka secara utuh (tentang diskursus gender), kita akan terlebih dahulu digiring pada hipotesa konsep-konsep equality, hingga hal-hal yang paling substantif, yaitu redaksi-redaksi hadits yang bersifat misoginis.

Sebaliknya bisa ditebak, jika kita membaca literatur-literatur klasik, khsusnya dalam hal ilmu fiqh dan tafsir, seperti karya imam madzhab yang empat, hingga para pengikut-pengikutnya, Imam Nawawi, Imam Ibnu Hajar, Imam Ramli, Imam Zamakhsyari, Imam Qurtubi, hinggga Imam Ibnu Katsir dengan kitab tafsirnya yang sangat fenomenal. Kemudian di susul oleh para ulama kholaf seperti Syaikh Nawawi alBantani, Syaik Sholeh darat, Syaikh Kholil bangkalan, dll, hampir telah dapat dipastikan, bahwa semua karyanya yang menyinggung tentang perkara wanita, baik dalam menafsirkan suatu ayat, mensyarahkan sebuah hadits, atau membahas sub bab tentang fiqh al-nisa, mereka hanya akan memberi garis lurus sejalan dengan apa yang pernah disabdahkan oleh Rasulullah. Atau dengan kata lain, upaya mereka dalam memberikan ta'liq dan syarah, tidak akan mungkin keluar dari batasan dan faming sebuah redaksi.

Dua kubu ini seakan tidak akan dapat disatukan, atau minimal ditemukan jalan tengahnya. Satu golongan mengatakan bahwa kehormatan wanita adalah jika kita mampu memuliakannya tanpa dilibatkankan dengan publik. Ditambah lagi dengan penempatan mereka satu tingkat di bawah kaum laki-laki. Satu kubu lagi mengatakan, bahwa sudah saatnya wanita memiki figur di mata publik, dan terhindar dari jerat pingitan, seperti apa yang telah terjadi sekian abad lamanya pasca diutusnya Muhammad sebagai seorang Rasul.

\section{Kedudukan wanita}

Sebelum kita berdebat antara mana posisi wanita yang paling objektif, kita harus terlebih dahulu mengetahui posisi wanita di masa pra dan pasca diutusnya Nabi Muhammad sebagai seorang Rasul. Semua para cendekiawan muslim, baik klasik maupun kontemporer, baik yang pro atau kontra terhadap isu-isu kesetaraan gender dan gerakan kaum feminis, mereka bersepakat, bahwa jika wanita menjadi objek kajian, sumber yang pertama kali digali adalah Al-Qur'an dan Al-Sunnah, dan keduanya tentu berada di masa Rasulullah.

Ini yang menjadi menarik, bahwa terkadang dalam sebuah diskursus ilmiah, litertur yang digunakan serupa, namun memiliki istinbath hukum yang berbeda. Hal-hal seperti ini sudah menjadi perkara lumran dikalangan para intelektual muslim lintas zaman, khususnya para fuqaha. Seperti hukum bersentuhan kulit lawan jenis yang bukan mahram, empat madzhab memiliki argumentasi yang berbeda, namun redaksi yang 


\section{Pemaknaan Kembali Konsep Wanita di Era Modern (Studi Atas Gagasan Kaum Feminisme dan Fundamentalis)- Rizal Al Hamid \\ DOI: https://doi.org/10.31004/edukatif.v4i1.2072}

digunakan adalah sama, yaitu QS Al-Maidah ayat 6. Serupa halnya dengan proses pengambilan hukum di atas, tidak menutup kemungkinan, bahwa para kaum feminis kerap kali menggunakan dasar hukum yang serupa dengan para kaum fundamentalis, namun masing-masing di antara mereka memiliki pisau analisis yang berbeda. Seperti pemahanan tentang makna qawwam dalam QS Al-Nisa ayat 34, atau makna jilbab dalam QS Al-Ahzab ayat 59 (Al-Suyuthi, 2013) yang masing-masing antara kedua ayat tersebut, selalu memiliki dua wajah saat berhadapan dengan dua kubu yang juga saling bertolak belakang.

Karakteristik yang sangat signifikan dari dua aliran di atas adalah, bahwa pada umumnya, kaum feminis selalu berfikir dinamis, progresif, solutif, visioner, dan rleatif keluar dari teks, yaitu dengan meninjau sisi histori, sehingga menjadi konteks yang relevan oleh zaman, dan dapat dikonsumsi oleh orang di zaman tersebut (Karim, 2018). Sebaliknya, kaum fumdamentalis kerap enggan untuk keluar dari teks, dan tetap kokoh dengan redaksi yang ada. Bumbu yang mereka gunakan pada umumnya sikap sosial masyarakat di masa tersebut, terhadap teks Hadits atau Al-Qur'an (Daven, 2019) atau dalam kata lain, bagaimana masyarakat kala itu memperlakukan redaksi, agar tidak keluar dari koridor syar'i. Barangkali inilah satusatunya nilai historis yang kaum fundamentalis gunakan, dari banyak pemikirannya yang cenderung normatif.

Dalam sejarahnya, telah banyak diketahui bahkan oleh orang awan sekalipun, bahwa hadirnya islam di bumi arab yang dibawa oleh putra Abdullah, salah satunya adalah untuk memberantas ketidakadilan terhadap kaum Hawa. Wanita saat itu tidak lebihnya seperti barang dagangan, yang jika pemiliknya menginginkan untuk dijual, maka dengan entengnya ia lakukan tanpa beben yang berarti. Perbudakan, tempat-tempat prostitusi, ayah mengawini anak sendiri, wanita tidak bisa menerima harta warisan, hingga rasa malu memiliki anak perempuan yang mengakibatkan mereka dikubur hidup-hidup, sudah menjadi habitus yang mengakar kuat bagi mereka orang-orang arab jahiliyah.

Berabad-abad lamanya sebelum hadirnya Rasul akhir zaman di bumi arab, eksistensi wanita selalu dipandang rendah, dan hanya ditempatkan sebagai makhluk domestik, yang keberadaannya hanya diekspolitasi, dan sebatas untuk kepentingan seksualitas kuam laki-laki (Nuryati, 2018). Belum lagi tanggungan rasa malu yang telah mensugesti di kalangan bangsa arab saat diketahui memiliki anak perempuan. Rasa malu itu bahkan hingga para orang tua, tidak segan-segan untuk mengubur hidup-hidup jabang bayi yang baru dilahirkannya.

Sekilas sejarah wanita pada masa jahiliyah di atas sama-sama di jadikan argumen oleh dua kubu faham yang saling bertolah belakang. Kaum fundamentalis menjadikan Rasulullah sebagai sosok mutlak dan final, yang berperan sebagai figur pemberantas ketidakadilan dengan langkah-langkan persuasif. Sehingga dengan hal ini, mereka berhak memberikan dalil-dalil, bahkan langkah Rasulullah ini adalah langkah final dari sebuah hukum, seperti halnya yang termaktub dalam QS Al-Maidah ayat 3, tidak ada yang berhak merevisi hukum apalagi sampai mendekonstruksikannya.

Lain halnya dengan kaum feminis yang selalu berfikir dinamis dan progresif dalam semua kajian yang berkenaan dengan gender. Sebagai contoh, bentuk penghargaan Rasulullah terhadap kaum Hawa kala itu adalah dengan memerintahkan kepada para sahabat yang memiliki istri, saudara, atau anak-anak perempuan, dengan selalu menutup aurat, dan keluar dengan didampingi oleh mahramnya. Upaya-upaya Rasulullah ini dilakukan ditengah masyarakat yang masih menganggap sebelah mata kaum wanita. Menurut kaum feminis, zaman telah berubah, sehingga kini kaum laki-laki tidak lagi memandang kaum wanita hanya sebagai pemuas nafsu belaka, namun harus bersama ditempatkan sejajar dan proporsional dalam hal bersosial, bermasyarakat, hingga menduduki jabatan strategis di sebuah instansi.

Sisi historis yang dijadikan pijakan oleh kaum feminis, mejadikan hukum tentang wanita seperti ini menjadi bias oleh kalangan fundamentalis. Bagaimana tidak, dengan perangkat metodologi yang mereka miliki, ditambah dengan realita sosial budaya yang mereka komparasikan antra zaman modern saat ini dengan 14 abad silam, tentulah memilik perbedaan yang sangat kontras. Sebenarnya bukan hal semacam itu yang kaum fundamentalis harapkan dalam sebuah diskursus ilmiah hingga menjadi sebuah kesimpulan hukum, 


\section{Pemaknaan Kembali Konsep Wanita di Era Modern (Studi Atas Gagasan Kaum Feminisme dan Fundamentalis)- Rizal Al Hamid}

DOI: https://doi.org/10.31004/edukatif.v4i1.2072

namun lebih kepada bagaimana dan seberapa besar kaum feminis memurnikan nash-nash Al-Qur'an dan hadis, agar tidak keluar dari kordor syar'I (Rosidah, 2019). Baginya, sabdah-sabdah Rasulullah tentang wanita adalah final, sehingga pasca wafatnya beliau hingga detik ini, tidak ada yang berhak untuk merekonstuksi ajaran-ajarannya. Upaya inilah yang terus dipertahankan dari pasca wafatnya Rasulullah, hingga mengakar berabad-abad lamanya. Barulah perlahan akar itu mulai tercabut di era modern seperti saat ini.

Benar saja, upaya Rasulullah ini sungguh membuahkan hasil yang mengagumkan. Kurang dari 23 tahun, beliau telah mampu memutar balikkan realita, hingga kaum hawa kembali memiliki nilai di mata lawan jenisnya. Mendapatkan separuh harta warisan dari laki-laki, menjadi saksi dalam sebuah perselisihan atau transaksi, bahkan hingga balasan surga, Allah tempatkan di bawah telapak kaki mereka. Hal tersebut tentu merupakan sebuah penghargaan besar, yang sebelumnya mereka hanya dijadikan sebagai budak pemuas nafsu.

Kini berbeda dengan dulu, entitas wanita saat inilah yang dijadikan barometer hukum oleh kaum feminis, sehingga sulit dicari titik temu antara mereka dengan kaum fundamentalis yang kontrak terhadap seluruh perangkat pemikirannya. Menurut mereka, perbedaan kaum wanita hanya sebatas kodrati dan universal (Muhammad, 2019) selebihnya, dalam aspek gender, dua jenis makhluk Allah ini memiliki potensi dan porsi yang sama di mata publik. Hal semacam ini (baca: status perempuan) biasa mereka sebut dengan konstruksional dan kontekstual. Konstruksional lantaran mereka berusahan merevisi hukum-hukum, dan tafsir-tafsir konvensional, yang dirasa mendeskriditkan kaum wanita. Dan kontekstual lantaran sebuah redaksi, harus sejalan dengan sisi historis, sehingga kondisi sosial budaya harus selalu menjadi bahan pertimbangan, agar siapa saja dapat menikmati hukum tersebut, tanpa merasa direndahkan, apalagi diperlakukan secara tidak adil.

Keterlibatan kaum hawa di hampir seluruh sektor publik di era modern ini, menjadikan teks-teks AlQur'an dan Hadits dirasa perlu untuk kembali dikaji ulang oleh para kaum feminis. Relevansi demi relevansi, hingga titik temu yang dapat mengiyakan seluruh argumen kaum feminis terhadap siapa saya yang setuju dengan pendapatnya, seakan mampu mematahkan hukum dan budaya yang sekian abad lamanya telah menjadi gaya hidup kaum hawa di masanya.

\section{Dampak Renaisans dan Tumbangnya Kesultanan Turki terhadap Kaum Wanita}

Konteks sosial dan budaya di era modern saat ini seakan menjadi jawaban bagi kegelisahan kaum feminis yang keberadaannya telah ada lebih dari satu abad yang lalu. Berangkat dari kegelishannya yang merasa para kaum wanita diperlakukan secara subordinat atau the second class, dimarjinalkan, hingga menjadi wanita pingitan sepanjang usia mereka. Keadaan seperti ini hingga membawa kesimpulan bagi kaum feminis, bahwa jika hal seperti ini terus saja berlangsung, mereka kaum Hawa akan selamanya terkekang dalam dunia patriarkisme, dan selamanya pula kaum Adam akan mejadi makhluk superior, yang berkedudukan satu strata lebih tinggi dari lawan jenisnya.

Dalam salah satu tulisannya, Husein Muhammad mengatakan, bahwa laki-laki dan perempuan dibedakan hanya dalam kaitanya dengan aspek biologis. Aspek ini bersifat kodrati dan universal. Lebih lanjut lagi ia mengatakan, bahwa di sisi lain, kedua jenis kelamin ini memiliki potensi kemanusiaan yang sama. Dalam hal ini, perbedaan mereka bersifat konstruksional dan kontekstual (Muhammad, 2015).

Jika ditarik garis sejarah di masa lalu, tepatnya di era renaisans, sedikit akan kita temukan titik terang, dari siapa dan bermula dari hal apa candu argumen tentang isu-isu kesetaraan gender, hingga membuat istilah tentang ayat-ayat dan hadits-hadits misoginis. Hal ini penting untuk kita telusuri, agar sebagai masyarakat muslim tidak merasa paling benar, apalagi saling menyalahkan satu sama lain.

Seperti yang dikatakan oleh Philip K Hitti dalam History of the Arabs, bahwa sekitar abad 15 hingga 17, ilmu pengetahuan telah hampir sepenuhnya dibawah kendai orang-orang Eropa. Selama ini kita hanya sebatas mengetahui bahwa dalam proses tersebut, mereka orang orang Eropa berubah menjadi mkahluk super 


\section{Pemaknaan Kembali Konsep Wanita di Era Modern (Studi Atas Gagasan Kaum Feminisme dan Fundamentalis)-Rizal Al Hamid \\ DOI: https://doi.org/10.31004/edukatif.v4i1.2072}

power, yang dahulunya hanya sebatas bertempat tingga di kemah-kemah kumuh, dan bahkan tidak tahu dunia baca dan tulis. Namun hal yang terlupakan oleh kita adalah, upaya mereka dalam membebaskan belenggu keterpasungan kaum wanita, yang dalam proses berfikirnya, islam itu agama yang sempurna, namun minus akan isu-isu seputar wanita.

Isu inilah yang coba mereka angkat, sejalan dengan proses transfer of knowledge yang di lakukan olehorang-orang Eropa (Hidayatul, 2018). Perlahan tapi pasti, upaya tersebut seakan tidak membuahkan hasil, bahkan hingga di abad 19, upaya orang-orang barat dalam menyamaratakan status gender, hingga menempatkan wanita di ruang publik, hampir-hampir belum terlihat pasti hasilnya. Upaya demi upaya seperti ini belum sepenuhnya kita judge bahwa era renaisans adalah gerakan untuk memposisikan wanita setara dengan laki-laki, karena telah bersama kita ketahui, bahwa era tersebut yang menjadi pangkal tolak adalah proses transfer ilmu pengetahuan.

Hasil akhir yang sudah tampak terlihat adalah saat kesultanan Utsmaniyah berhasil ditumbangkan pada tahun 1924. Peristiwa tersebut tidak saja menjadi isu politik global, namun juga menyangkut harkat dan martabat kaum Wanita (Maulana, 2019). Larangan mengenakan jilbab, dihapuskannya pelajaran agama di sekolah-sekolah, dirubahnya huruf arab dengan alphabet, hingga larangan adzan menggunakan bahasa arab dan harus menggunakan bahasa setempat, menjadi tinta hitam sejarah yang amat kelam, yang berhasil dilakukan oleh Musthafa kamal beserta antek-anteknya. Feedback yang kemudian dirasakan adalah tidak adanya batasan antara penganut agama satu dengan yang lain, berubahnya sistem pemerintahkan menjadi Republik, bercampur-baurnya antar lawan jenis di hampir semua aktifitas, hingga dilibatkannya kaum wanita dalam posisi strategis di pemerintahan. Hal-hal semacam ini memunculkan banyak kelatahan di hampir semua penganut muslim di seluruh dunia, khususnya di Nusantara, yang kala itu hampir belum terjamah oleh westernisasi.

Dari berbagai pihak, para muslimin dihadapkan dengan tantangan yang serupa, yaitu isu kesetaraan gender hingga gerakan massif kaum feminis, yang mengakibatkan banyak lini merekonstruksi hukum sosialbudaya di wilayahnya masing-masing. Hal ini memang bukan suatu yang baru di belahan Negeri Eropa dan Amerika, karena merekalah yang kali pertama mencampur adukkan antara dua gender dalam banyak situasi soaial, khususnya instansi pemerintahan. Keadaan seperti inilah yang oleh para petinggi muslim, yang memiliki pemikiran progresif dan sekuler, membuat kebijakan serupa dengan Negeri-negeri non muslim. Seperti telah kami singgung di atas, adalah Negara Turki modern, wilayah dengan penduduk muslim terbanyak di belahan bumi Eropa, yang di pimpin oleh Attaturk.

Sebagain besar muslimin kala itu menentang keras akan kebijakan-kebijakan kontroversi yang dicetuskan oleh Attaturk, khususnya kebijakan yang berkaitan dengan isu gender, yang diras oleh sebagian besar muslimah kala itu merasa direndaahkan martabat dan hargadirinya. Bisa dikatakan, Turkilah Negeri muslim pertama yang mengalami kelatahan akan situasi isu gender di Eropa dan Amerika. Sampai di sini kita telah memiliki gambara, bagaimana sejarah panjang perdebatan antara kaum feminis dengan fundamentalis belum juga usia. Sebenarnya bukan masalah selesai atau tidaknya perdebatan ini berlangsung, namun bagaimana kita mensikapi keadaan seperti ini. Sederhananya, kaum feminis dapat dikatakan bahwa mereka tidak akan mampu merealisasikan semua gagasan dan argumen, sekalipun banyak dari nash Al-Qur'an dan Hadis yang banyak menjadi bahan bulan-bulanan. Terlebih telah sekian puluh tahun predikat hadits-hadits misoginis banyak menjadi perhatian dikalangan akademisi, dan umat muslimin secara umum, yang dirasa terlalu mengada-ngada akan ketidakadilan islam terhadap kaum wanita. Ketidakmampuan kaum feminis dalam mewujudkan upaya tersebut tidak lain lantaran masih banyak dari para akademisi muslim, dan ulama pada umumnya, secara berbondong-bondong memberikan sanggahan hingga gugatan, demi mematahkan argument demi argumen kaum feminis, yang telah mengkontekstualkan nash hingga keluar dari framing syar'i. 


\section{Pemaknaan Kembali Konsep Wanita di Era Modern (Studi Atas Gagasan Kaum Feminisme dan Fundamentalis)- Rizal Al Hamid \\ DOI: https://doi.org/10.31004/edukatif.v4i1.2072}

Sebaliknya, arus modernitas, perubahan zaman, hingga proses westernisasi yang hingga kini masih berjalan, seakan tidak mampu untuk membendung arus feminisme yang setiap saat, ada saja upaya-upaya mereka dalam memperjungkan harkat dan martabat kaum hawa, yang oleh para ulama salaf, bahkan hingga Rasulullah, harkat dan martabat kaum hawa hanya dapat diraih jika wanitanya berjuang di balik kayar, tapa harus bersusah payah menyetarakan diri sejajar dengan kaum Adam.

\section{Pemaknaan Teks}

Seperti yang sedikit telah kami singgung di atas, bahwa perbedaan pendapat ulama terkadang justru berasal dari pemaknaan sumber teks yang sama. Hal inilah yang justru menambah khazanah keilmuan islam, yang sudah sepatutnya ditempatkan sejalan dengan keadaan sosial dan sisi historis dari teks itu sendiri, baik itu asbab al-wurud sebuah teks hadits, atau asbab al-nuzul sebuah nash Al-Qur'an.

Al-Qur'an dan hadits memang merupakan sumber otoritatis lintas zaman bagi umat muslim di seluruh dunia. Sebagai teks, tentu di dalamnya terdapat ragam interpretasi, dari para cendekiawan muslim otoritatif. Dari sifatnya yang interpretatif itulah sebuah teks memiliki potensi pluralitas tak terbatas, dan multi dimensional/perpektif (Muhammad, 2015). Sejalan dengan hal tersebut, para ulama klasikpun sebenarnya telah banyak memberikan jalan keluar, saat mereka mengalami kebuntuan berfikir dalam memahami literatur teks. Bahkan Rasulullah pun membenarkan dua kubu sahabat yang berselisih saat mereka menuju ke wilayah Bani Quraidhah.

Dalam hal ini, Imam Ghazali pernah berkata, bahwa mereka yang menganggap bahwa Al-Qur'an hanya memiliki makna literal saja, sebenarnya ia sedang menceritakan akan keterbatasan ilmunya sendiri, dan biarlah itu menjadi pembenar bagi dirinya sindiri. Sebuah hal yang keliru jika ia berusaha menarik orang pada pemikirannya itu. Berapa banyak teks-teks Al-Qur'an dan Hadits yang memiliki makna tidak hanya sebatas literalnya saja, namun ia bagai lautan, yang dapat diarungi oleh semua orang. Hal-hal seperti ini hanya dapat dicerna oleh orang-orang pandai ((Al-Ghazali \& Muhammad, 2013).

Sejalan dengan hal di atas, Muhammad Syahrur seorang pemikir muslim dari Syria bahkan mengatakan bahwa pemaknaan sebuah teks, adalah interpretasi yang mengentas pemahaman agar tidak ambigu. Sangat jauh berbeda dengan ijtihad, yang dalam prosesnya, ia bisa saja berubah, sesuai dengan kondisi sosial budaya yang berbeda pula. Lagu pula, lanjut Syahrur, bahwa ijtihad merupakan proses dimana bahasa hukum digunakan untuk menghasilkan hukum tertentu yang menyesuaikan waktu dan tempat Sebuah contoh kasus poligami yang terjadi di masa pra diutusnya Muhammad menjadi seorang Rasul, dan kala beliau menjadi Rasul. Selama ini kita hanya mengetahui akan kemubahan status hukum poligami, yang termaktub dalam QS Al-Nisa ayat 3 dan 129. Secara normatif kita mungkin akan mengatakan bahwa poligami adalah boleh, atau bahkan secara subjektif kita mengatakan sunnah.

Dalam wacana ilmiahnya, Syahrur memberikan gagasan progresif akan polemik di atas, ia mengutarakan bahwa di antara wacana keadilan dan kesetaraan yang diperjuangkan oleh islam adalah, persamaan hak antara kaum laki-laki dan perempuan (Al-Ghazali \& Muhammad, 2013). Hal ini merupakan proses brilian yang dilakukan oleh Rasulullah, melihat ketimpangan demi ketimpangan yang terjadi di masa itu, sehingga Ia mereformasi bentuk ketidakadilan terhadap kaum perempuan. Praktik-praktik poligami tanpa batas diganti dengan poligami terbatas, itupun banyak tanda kutip yang perlu dipenuhi persyaratannya. Hal yang serupa juga terjadi dalam perkara perkawinan, dimana antar pihak, masih menganggap prosesi perkawinan seperti perdagangan yang bersifat transaksional. Dengan demikian, islam merubah status serah terima harta dengan wanita layaknya jual beli, dengan konsep mahar yang lebih manusiawi.

Untuk dapat mencerna sebuah teks (dalam hal ini adalah Al-Qur'an dan hadits), seseorang tidak sebatas memiki data base hafalan yang banyak lagi kuat, atau setumpuk metotologi yang progresif, namun diperlukan perangkat kesinambungan antar keduanya, agar dalam mengambil sebuah kesimpulan hukum, tidak terjadi ketimpangan, dan bias pemahaman. Inilah yang dilakukan oleh Imam Syafi'i tatkala mencetuskan sebuah 


\section{Pemaknaan Kembali Konsep Wanita di Era Modern (Studi Atas Gagasan Kaum Feminisme dan Fundamentalis)- Rizal Al Hamid}

DOI: https://doi.org/10.31004/edukatif.v4i1.2072

istinbath hukum. Bagi mereka yang cerdas akan mengetahui, bahwa perubahan qaul Imam Syafi'i dari qadim menjadi jadid, tidak semata-mata sikap beliau yang inkonsisten, namun justru nilai pertimbangan kondisi sosio-cultural tempat dimana beliau memutuskan sebuah produk hokum.

Dalam sebuah perangkat metodologi, akan kita temukan banyak pisau analisis dan pendekatan, hingga menjadi sebuah kesimpulan hukum. Pengetahuan bahasa yang mendalam, nalar rasio, komparasi antar teks dan qaul antar ulama otoritatif, isyarat-isyarat, simbol-simbol, perubahan kondisi sosial budaya, konteks yang mendahului (al-Sawabiq) dan yang menyertainya (al-Lawahiq), serta kesepakatan (ijma') oleh jumhur ulama, merupakan kunci mutlak dalam proses pengambilan hukum (Hariati, 2019). Singkatnya, perangkat metodologi yang dilakukan oleh ulama-ulama otoritatif, tidak lepas dari upaya analisis mereka terhadap kehadiran kondisi sosial-budaya, tujuan dan dampak, sebab akibat, dan kehadiran teks itu sendiri.

Syahrur saat memaknai konsep sunnah misalnya, dalam teori batasnya, (nadzariyat al-hudud) ia kerap memberikan sanggahan, terutama bagi para pemikir klasik, seperti imam madzhab yang empat, dan mufassir lintas zaman di era keemasan islam, bahwa sunnah seharusnya dimaknai dengan proses yang sedang berlangsung, dan bukan dimaknai sebagai contoh yang sudah sempurna atau final. Pada akhirnya, terdapat sisi historis-kontekstual di setiap teks, yang dalam tujuannya, (maqashid al-syar'iyah) bukan semata memandang sempit makna sebuah teks, namun juga harus melihat mashlahah yang lebih menyeluruh di kalangan umat islam (mashalih al-'ammah).

\section{Titik temu}

Setelah mengetahui seluruh alur pembahasan pada tulisan sederhana ini, terdapat satu pokok bahasa yang menjadi titik bertemunya antara kaum feminis dengan sagala argumen kontekstual dan konstruksionalnya, dan mereka kaum fundamentalis dengan segala argumen normatifnya, yang berusaha tidak keluar dari keotentikan teks-teks otoritatif (baca: Al-Qur'an dan Hadits), agar sebagai masyarakat awam, tidak lagi resah atas dua pemikiran yang saling kontra persepsi dan kontra ideologi tersebut.

Dalam berislam, kita tentu mengenal makna rukum islam yang lima, karena islam itu sendiri dibangun atas lima hal tersebut. Jika diklasifikasikan, terdapat dua kategori besar sebagai pedoman dan jalan hidup sebagai seorang muslim. Pertama adalah aqidah, pada pembagian pertama ini, hanya ada satu pokok besar yang masuk pada kategori tersebut, yaitu mengucapkan dua kalimat syahadat (Al-Asy'ari \& Hasan, 2019). Dengan segala konsekwensi yang ada, saat kita melafalkan dua kalimat sakral tersebut, itu berarti kita telah berikrar, bersumpah, dan menyatakan janji setia terhadap agama islam, sehingga saat terjadi gonjang-ganjing keimanan dalam hati, atau mendapat penawaran untuk berganti agama walau sesaat, syahadat menjadi jurus ampuh sebagai alat penepisnya. Hal ini seperti yang terdapat dalam QS: Al-Kafirun, yang dalam sebab turunya, orang-orang kafir memberi tawaran kepada Rasulullah beserta para sahabatnya untuk berganti agama, dengan feedback merekapun akan masuk pada agama Islam. Atau pula yang terdapat dalam QS: Al-Isra ayat 74-75, saat orang-orang kafir memberi penawaran pada kaum muslimin, bahwa sebelum mereka menyentuh hajar aswad, terlebih dahulu mereka diminta untuk menyentuh berhala-berhala yang ada di sekeliling Ka'bah, pun dengan feedback sebaliknya (Refileli, 2019). Hal tersebut segera mendapatkan teguran dari Allah, yang Ia jawab dalam QS: Al-Baqarah ayat 208, bahwa para muslimin diperintahkan untuk masuk islam secara kaffah, dengan tanpa ada timbal atau iming-iming walau sesaat. Alhasil, dalam beraqidah, tidak ada kompromi saat kita dihadapkan dengan perkara yang dapat merusak keimanan kita, sehingga secara prosedural hukum, tidak ada proses seperti pion kedua yang akan kami paparkan setelah ini.

Kedua adalah ibadah dan mu'amalah. Agar lebih mudah mencernanya, kami masukkan dua amaliyah ini ke dalam satu kategori. Ibadah yang dalam hal ini adalah sholat, puasa dan haji, serta mu'amalah dalam hal ini adalah zakat, beserta turunannya, seperti shadaqah, waqaf, infaq, hibah, dll, beserta perkara-perkara umum dalam hal mu'amalah lainnya, seperti dalam aspek sosial, budaya, politik, pendidikan, ekonomi, dsb, 


\section{Pemaknaan Kembali Konsep Wanita di Era Modern (Studi Atas Gagasan Kaum Feminisme dan Fundamentalis)- Rizal Al Hamid}

DOI: https://doi.org/10.31004/edukatif.v4i1.2072

semua amaliyah tersebut, baik yang bersifat ubudiyah maupun mu'amalah, atau mahdhah maupun ghairu mahdhah, memiliki graduasi dalam proses turun hingga aplikasinya.

Sebagai contoh, dalam prosesnya, ayat yang menerangkan tentang konsep khamr, tidak semerta-merta Allah haramkan begitu saja, namun di dalamnya terjadi alur dan tahapan yang begitu panjang, hingga pada kesimpulan, bahwa khamr adalah salah satu dari rijsun min 'amal al-syaithan (perbuatan keji dan termasuk dari perbuatan setan). Terdapat cukup banyak ayat-ayat di Al-Qur'an, yang secara hukum, tidak semerta-merta Allah fonis perkara tersebut akan keharaman atau larangannya. Bahkan dalam beberapa kasus, beberapa ayat telah terhapus hukumnya, lantaran Allah datangkan dengan hukum yang lebih ringan (baca: nasikh wa mansukh).

Jika diperhatikan, seluruh ayat yang membahas tentang non aqidah, ayat-ayat tersebut hampir semuanya turun berdasarkan graduasi situasi dan kondisi masyarakat kala ini. Pada akhirnya, saat Rasulullah telah membentuk moral orang-orang arab dari yang berwatak keras, hingga penuh dengan penyakit hati, menjadi melah lembut dan setia memperjuangkan islam, barulah ayat-ayat tentang ibadah turun secara berkala dan bertahap, hingga tidak ada satupun sahabat yang merasa keberatan untuk mendirikan sholat lima waktu, puasa sebulan penuh, hingga menyisihkan sebagian hartanya untuk si papa.

Jika kembalikan pada dua poin besar di atas, yaitu aqidah, dan ibadah sekaligus mu'amalah, akan kita dapati diskursus tentang gender, khususnya feminisme, bukanlah masuk pada ranah aqidah (Lubis, 2019). Sehingga dapat disimpulkan, bahwa dalam aplikasinya, tedapat proses yang membawa kaum Hawa agar menjadi pribadi yang lebih baik. Di dalam Al-Qur'an, pembahasan tentang wanita yang isunya kembali diangkat oleh kaum feminis, tidak lepas dari pembahasan seputar makna qawwam, poligami, hak waris, kesaksian, dan jilbab, selebihnya adalah turunan dari bembahasan-pembahasan tersebut. Di dalam haditspun tidak jauh berbeda, hanya tekadang kaum feminis lebih menekankan pada isu-isu seputar hadits-hadits misoginis, yang dirasa oleh mereka terlalu mendeskriditkan kaum wanita.

Alhasil, seluruh dari kasuistik dan problematika yang diangkat oleh kaum feminis, sekali lagi, tidak ada satupun pembahasan yang menyangkut tentang aqidah, sehingga dalam pengamalannya, masih tedapat kompromi, agar masing-masing individu, khususnya para wanita, menyadari akan kedudukannya di era modern saat ini. Atau dalam arti lain, bahwa dalam berislam, setiap saat dan waktu, tingkat keshalihan seseorang tentu harus terus meningkat, hingga mencapai derajat muttaqun atau menjadi orang-orang yang bertaqwa. Di sinilah seharusnya kita memiliki kesadaran, khususnya kaum hawa, agar dalam mencerna sebuah dalil, proses memahami, hingga pengamalannya, tidak lantas mengambil yang mudah-mudah saja, namun harus dilihat konsekwensi hingga balasan yang Allah berikan kelak. Sebagai contoh dalam hal berjilbab, memang sebagian kecil ulama ada yang mengatakan bahwa jilbab itu tidak wajib, berdasarkan kontekstualisasi dan sisi historis yang terkandung dalam QS: Al-Ahzab ayat 59, namun apakah kita akan selamanya mengiyakan pedapat minoritas yang belum tentu nemiliki nilai keabsahan, dibanding dengan jumhur, yang bukan hanya sebatas memiliki dominasi kebenaran, namun juga terdapat ruh akan tingkat ketaqwaan di dalamnya. Begitupun dengan isu-isu lainnya seputar gender dan feminisme, bisa dikatakan, bahwa feminisme adalah proses berfikir yang belum menemukan titik terang, sehingga kaum wanitanya mencoba mereka ombang-ambingkan. Pada akhirnya, Jika terdapat kebenaran pada diri mereka, ambillah seperlunya, selama tidak bertentangan dengan nash-nash yang telah qath' $i$, namun jika terdapat kekeliruan, sudah sepatutnya bagi kita untuk meluruskan, atau minimal menjauhi gagasan-gagasan mereka. 


\section{Pemaknaan Kembali Konsep Wanita di Era Modern (Studi Atas Gagasan Kaum Feminisme dan}

Fundamentalis)-Rizal Al Hamid

DOI: https://doi.org/10.31004/edukatif.v4i1.2072

\section{KESIMPULAN}

Salah satu di antara dua golongan di atas, karena memang tujuan kami hanya sebatas memberikan pencerahan, agar bersama-sama kita mengetahui dari mana akar permasalahan ini bermuara. Di era serba modern seperti saat ini, dan dengan berkembangnya segala kebutuhan, sosial, budaya hingga teknologi, memunculkan gerakan yang menamai dirinya dengan kaum feminis. Walau dalam sejarahnya, gerakan ini tidak sepenuhnya dipelopori oleh kaum muslimin, namun dewasa ini, kita harus selektif dalam memilah dan memilih mana argumen mereka yang dapat dicerna nalar logika sejalan dengan teks-teks yang ada, dan mana argumen mereka yang secara terang-terangan keluar dari framing syar'i.

Setidaknya, selama tidak ada larangan konkret dan real yang menjadikan wanita sebagai makhluk pingitan, terdapat banyak alternatif agar tidak sepenuhnya kita menganggap keliru semua argumen yang dibawakan oleh kaum feminis. Sebalikya, selama masih kita temukan kemurnian teks-teks Al-Qur'an dan Hadits yang menjadikan wanita makhluk istimewa, kaum feminis juga tidak berhak mengatakan bahwa redaksi-redaksi tersebut terlalu mendeskriditkan entitas kaum wanita, hingga memberi kesimpulan bahwa tindakan tersebut merupakan bentuk ketidakadilan.

Di satu sisi, kitapun harus kembali pada salah satu prinsip dasar islam yang telah kami sampaikan di atas, bahwa menjaga atau melanggengkan urf yang telah ada sejak lama, tidak layak bagi kita untuk menguburnya begitu saja, sekalipun kita hidup di era serba modern saat ini. Terdapat banyak 'ibrah yang justru kita dapatkan dari para pendahulu-pendahulu kita, sehingga secara tidak langsung, hadirnya kita sekaligus menjadi representasi akan langgengnya budaya itu sendiri, dalam hal ini adalah mempertahankan dan menyeimbangkan entitas wanita di abad 21 ini, agar tetap dalam koridor syar'i, baik dalam beragama, bersosial, maupun bernegara. Sebaliknya, mengambil sesuatu yang baru, dalam hal ini adalah seperangkat pemikiran kaum feminis, tidak sepenuhnya kita tolak selama hal tersebut masih memiliki dasar hukum dalam menjalankannya.

Pada akhirnya, setelah kita mengetahui seluruh alur proses brfikir di atas, satu poin lagi yang menjadi titik temu antar keduanya, yaitu memahami secara holistik makna seseorang dalam berislam. Di dalamnya terdapat pondasi aqidah (dua kalimat syahadat), memiliki penegak syari'at (sholat, puasa, dan haji), serta beratapkan mu'amalah (zakat, infaq shadaqah, dsb, sosial, budaya, politik, pendidikan, dll). Aqidah dalam hal ini tidak ada kompromi, dan tidak bisa ditukar walau hanya hanya sesaat, oleh sebab itu, seluruh ayat dalam Al-Qur'an yang berkenaan dengan aqidah, Allah tidak menurunkan proses dalam menjalaninya, seperti yang terdapat dalam QS Al-Kafirun dan QS: Al-Isra 74-75, yang kemudian Allah jawab dengan ayat 208 dalam QS: Al-Baqarah. Sangat jauh berbeda dengan ayat-ayat non aqidah, baik itu tentang kisah-kisah, fiqh, hingga moral, seluruhnya Allah turunkan menyesuaikan dengan tingkat kesiapan orang-orang arab, khususnya pada sahabat kala itu. Seperti kisah-kisah yang terdapat pada QS: Al-kahfi, fiqh waris, hingga konsep khamr yang tidak semerta-merta Allah haramkan begitu saja.

Dalam diskursus gender, khususnya tentang gerakan feminisme, kami rasa tidak ada satupun pembahasan yang menyoal tentang aqidah, sehingga terdapat banyak kelonggaran, selama tidak menyalahi batas dalam beragama. Yang perlu ditekankan adalah bukan seberapa kuat hujjah para kaum feminis, sehingga seluruh argumennya dapat diiyakan oleh banyak orang, khsusnya wanita di era modern ini, namun seberapa jauhkah tingkat keimanan kita, sehingga dalam berislam, yang di dalamnya banyak mewanti-wanti kita untuk terus meningkatkan iman dan taqwa, dapat selalu dioptimalisasikan hingga penghujung hidup kita. Jika dalam menjalankan gagasan-gagasan feminis, seseorang bisa menambah keimanan, tidak ada yang buruk untuk seseorang itu menerima gagasan tersebut, namun sebaliknya, jika gagasan-gagasan tersebut justru menjauhkan diri pada Sang Pencipta, sudah sepatutnya kita untuk menjauhi pendapat-pendapat mereka. Wallahu a'lam. 
1169 Pemaknaan Kembali Konsep Wanita di Era Modern (Studi Atas Gagasan Kaum Feminisme dan Fundamentalis)- Rizal Al Hamid

DOI: https://doi.org/10.31004/edukatif.v4i1.2072

\section{DAFTAR PUSTAKA}

Al-Asy'ari, \& Hasan, A. (2019). Peradaban Islam Al-Khulafa Al-Rasyidin. Jurnal Tsaqofan Dan Tarikh, 1(1). Al-Baghowi, A. M. H. (2009). Tafsir Al-Baghowi, Juz 1. Dar Al-Fikar.

Al-Din, A.-R. F. (2008). Al-Tafsir Al-Kabir, Juz 10. Dar Kutub Al-Ilmiyah.

Al-Ghazali, \& Muhammad, A. H. M. Bin. (2013). Ihya Ulum Al-Din, Juz I. Dar Al-Fikar.

Al-Suyuthi, J. Al-D. (2013). Al-Durr Al-Mantsur Fi Al-Tafsir Bi Al-Ma'tsur. Dar Al-Kutub Al-Ilmiyah.

Al-Zamakhsyari, A. Al-Q. (2008). Al-Kasyaf 'An Haqaiq Al-Tanzil Wa Uyun Al-Aqawil Fi Wujuh Al-Ta'wil, Juz 1. Dal Al-Kutub Al-'Arabi.

Arivia, Gadir, N. I. S. (2018). Seratus Tahun Feminisme Di Indonesia: Analisis Terhadap Para Aktor, Debat, Dan Strategi. Friedrich Ebert Stiftung.

Burhanuddin, Nunu, J. W. (2018). Akar Dan Motif Fundamentalisme Islam: Reformulasi Tipologi Fundamentalisme, Dan Prospeknya Di Indonesia. Jurnal Ilmiah Agama Dan Sosial Budaya, Juli, Vol $1(2)$.

Dahlan, F. (2019). Fundamentalisme Agama: Antara Fenomena Dakwah Dan Kekerasan Atas Nama Agama. Jurnal Ilmu Dakwah, 6 Juli-Des(2).

Daven, M. (2019). Fundamentalisme Agama Sebagai Tantangan Bagi Negara. Jurnal Ledalero, 15(2).

Fauzan. (2019). Fundamentalisme Dalam Islam. Jurnal Al-Adyan, 5(1).

Hariati, S. (2019). Aliran Feminisme Modern Dan Aliran Feminisme Menurut Islam. Jurnal Al Jatiswara, 19(1).

Hidayatul, A. I. (2018). Feminisme Indonesia Dalam Lintas Sejarah. Jurnal Temali: Jurnal Pembangunan Sosial, Vol. 1 No.

Ibnu Katsir, I. Al-D. I. (2013). Tafsir Al-Qur'an Al-Adzim, Juz 1. Dar Al-Kutub Al- Ilmiyah,.

Karim, A. (2018). Feminisme: Sebuah Model Penelitian Kualitatif. Jurnal Sawwa, 10(1).

Lubis, S. (2019). Gerakan Feminisme Dalam Era Post Modernisme Abad 21. Jurnal Demokrasi, 1(1).

Maulana, A. M. R. (2019). Feminisme Sebagai Diskursus Pandangan Hidup. Jurnal Kalimah, 11(1).

Muhammad, H. (2012). Gagasan Tafsir Feminis. Urnal Al-Qur'an Dan Hadits, 13(1).

Muhammad, H. (2015). Perempuan, Islam, Dan Negara. Qalam Nusantara.

Muhammad, H. (2019). Fiqh Perempuan: Refleksi Kiai Atas Tafsir Wacana Agama Dan Gender. Ircisod.

Nuryati. (2018). Feminisme Dalam Kepemimpinan. Jurnal Istinbath, 14(16).

Refileli. (2019). Peradaban Islam Al-Khulafa Al-Rasyidin. Jurnal Tsaqofan Dan Tarikh, 1(1).

Rosidah, N. (2019). Fundamentalisme Agama. Jurnal Walisongo, 20(1). 